\title{
Efektivitas Vitamin C Pada Daun Kelor Terhadap Bilangan Peroksida Dari Minyak Jelantah
}

\author{
Nastiti Kartikorini .ST,MKes., Eriana Yuniara Frastika* \\ *Program Studi Teknologi Laboratorium Medik, Universitas Muhammadiyah Surabaya \\ Email : nastitikartikorini@gmail.com
}

\begin{abstract}
Tanggal Submit: 19 Juni 2019

Tanggal Review: 24 Juli 2019

Tanggal Publish Online:

2 Oktober 2019

Used cooking oil is a cooking oil that has been used several times. Used cooking oil undergoes an oxidation reaction to produce high peroxide compounds. Phenolic compounds are primary antioxidants contained in Moringa leaves which slow the oxidation down in used cooking oil so that it can be stored longer.

Formulation of the problem in this study was whether there was an inhibitory test on Moringa oleifera Leaves powder on the peroxide value in used cooking oil. The purpose of this study was to determine the inhibition of Moringa leaves powder to peroxide value on used cooking oil. This type of research was an experimental i.e. to determine whether there was the inhibition of Moringa leaves powder to the peroxide value in used cooking oil. The sample in this study was 5 samples from 6 fried traders, and repeated 5 times so that the total sample was 25 samples. Peroxide levels could be decreased due to the antioxidant content found in Moringa leaves. Antioxidants found in Moringa leaves are phenolic components. Phenolic components can inhibit free radicals and inhibit peroxide value to decrease. Moringa was suitable for areas where strong and long winds, drought occur simultaneously, and cause serious soil erosion. Nutrient content in deciduous leaves could fertilize and improve marginal soil quality (Dudi, 2015). Therefore, Moringa leaves not only have high antioxidants but also could be found easily in Surabaya.

From the results of peroxide levels test, it was known that the average peroxide value in used cooking oil without Moringa leaves was equal to $23,9957 \mathrm{mEq}$ and with Moringa leaves by different time variation i.e. 1 day $(14,3182 \mathrm{mEq}), 2$ days $(10,7987$ $\mathrm{mEq}), 3$ days $(6,1593 \mathrm{mEq}), 4$ days $(3,0397 \mathrm{mEq})$. Statistical analysis with Anova test showed the inhibition of Moringa leaves powder to decrease in peroxide value on used cooking oil with a value of $\mathrm{p}(\mathrm{sig})=0,000$ which was less than 0.05 . Based on the results of the Tukey HSD test, the most effective soaking of Moringa leaves powder for 4 days was to reduce peroxide levels in used cooking oil by giving $5 \mathrm{gr}$ Moringa leaf powder with $100 \mathrm{ml}$ used cooking oil.
\end{abstract}

Keywords : Levels of Peroxide Value, Moringa Leaves, Used Cooking Oil 
The Joumal Of Muhammadiyah Medical Laboratiory

Vol.2No.2 Mei2019

p-ISSN: 2597-3681 e-ISSN:26142805

PENDAHULUAN

Vitamin merupakan suatu senyawa organik kompleks yang dibutuhkan tubuh dalam jumlah yang sedikit. Meskipun kebutuhan akan vitamin sangat kecil, tetapi vitamin sangat penting untuk proses pertumbuhan, mempertahankan kesehatan, dan proses metabolisme normal tubuh. Di dalam makanan, vitamin hanya terdapat dalam jumlah sedikit (Aulina, 2001).

Vitamin dibagi menjadi 2 kelompok yaitu : yang larut dalam lemak (vitamin A, D, E, dan K) dan yang larut dalam air (kelompok vitamin - vitamin C) (Isnaini, 2000).

Vitamin $\mathrm{C}$ adalah salah satu vitamin yang penting bagi tubuh. Vitamin ini mudah larut dalam air dan mudah rusak apabila dibiarkan lama terbuka di udara (oksidasi). Vitamin C cukup stabil dalam larutan asam dan dengan adanya cahaya akan mengalami kerusakan (Atmatsier, 2009).

Sumber vitamin $C$ sebagian besar berasal dari sayur dan buah buahan, salah satunya adalah daun kelor (Fuglie, 2001).

Pohon kelor sudah dikenal luas di Indonesia, khususnya di daerah pedesaan, tetapi belum dimanfaatkan secara maksimal dalam kehidupan di Indonesia, pohon kelor banyak ditanam sebagai pagar hidup, ditanam di sepanjang ladang atau tepi sawah, berfungsi sebagai tanaman penghijau. Selain itu tanaman kelor juga dikenal sebagai tanaman obat berkasiat dengan memanfaatkan seluruh bagian dari tanaman kelor mulai dari daun, kulit batang, biji, hingga akarnya (Nelly, 2007).

Daun kelor dikonsumsi sebagai sayuran dan teh dengan rasa yang khas, yang memiliki rasa langu dan juga digunakan untuk pakan ternak karena dapat meningkatkan perkembangbiakan ternak khususnya unggas. Selain dikomsumsi daun kelor juga di jadikan obat-obatan dan penjernih air (Anonim, 2004).

Potensi yang terkandung dalam daun kelor diantaranya tinggi kandungan protein, vitamin $\mathrm{C}$, mineral terutama zat besi dan kalsium (Fuglie, 2001), di Afrika dan Asia daun kelor direkomendasikan sebagai suplemen yang kaya zat gizi untuk ibu menyusui dan anak pada masa pertumbuhan. Produk-poduk yang berasal dari daun kelor yang kini sudah beredar dipasaran diantaranya; teh moringa, minyak , sayuran, dan minuman suplemen moringa (Anonim, 2007).

Daun kelor yang mempunyai potensi zat gizi seharusnya dimanfaatkan menjadi minuman teh. Merupakan minuman ringan bentuk teh, umumnya minuman teh diharapkan 
The Joumal Of Muhammadiyah Medical Laboratiory

Vol.2No.2, Mei2019

p-ISSN: 2597-3681 e-ISSN:26142805

menjadi alternativ minuman sari buah.

Keunggulan lain dari minuman teh adalah adanya kandungan vitamin dan serat alami yang berguna bagi metabolisme tubuh (Paranjaya, 2007).

Komsumsi daun kelor merupakan salah satu alternatif untuk menanggulangi kasus kekurangan gizi di Indonesia. Kandungan gizi tersebut diatas akan mengalami peningkatan kuantitas apa bila daun kelor dikomsumsi setelah dikeringkan dan di jadikan teh daun kelor (Juni M.S dkk. 2008). Minuman teh digunakan untuk meningkatkan nilai tambah daun kelor karena minuman yang digemari masyarakat, mudah dibawa atau dikirim dan juga pembuatan yang murah, baik diproduksi pada skala kecil maupun industri.

\section{METODE}

Jenis penelitian yang digunakan adalah penelitian eksperiment, yaitu untuk mengetahui kadar vitamin $\mathrm{C}$ pada teh daun kelor terhadap bilangan peroksida dari minyak jelantah

Penetapan kadar vitamin $\mathrm{C}$ :

Untuk penetapan kadar vitamin $\mathrm{C}$ ,ditimbang bahan teh daun kelor kering 10 gram,kemudian dihancurkan dengan blender samapai diperoleh bentuk bubur halus,dilanjutkan dengan dimasukkan kedalam labu ukur $50 \mathrm{ml}$,ditambahakan aquadest sampai tanda batas 50
ml.Dilanjutkan dipusingkan dengan centrifuge untuk memisahkan filtratnya,dilanjutkan dengan diambil 20 ml filtratnya dengan pipet ukur $10 \mathrm{ml}$ dua kali,dimasukkan kedalam Erlenmeyer sebanyak $125 \mathrm{ml}$ ditambahkan $2 \mathrm{ml}$ amilum $1 \%$ ,dilanjutkan dengan dititrasi untuk standartdisasi dengan larutan standart Iodium $0,01 \mathrm{~N}$ ml,dihitung jumlah volume hasil titrasi dari buret. Sumber. (Modul kimia amani, 2013)

Perhitungan : $1 \mathrm{ml} 0,01 \mathrm{~N}$ Iodium 0,88 mg Asam askrobat.

\section{Penetapan Kadar}

$\%$ Vit. $\mathrm{C}=\left(\mathrm{ml} \operatorname{Iod} \times \frac{N \text { lod }}{0,01}\right) \times 0,08 \times$ pengenceran $\times 100 \%$
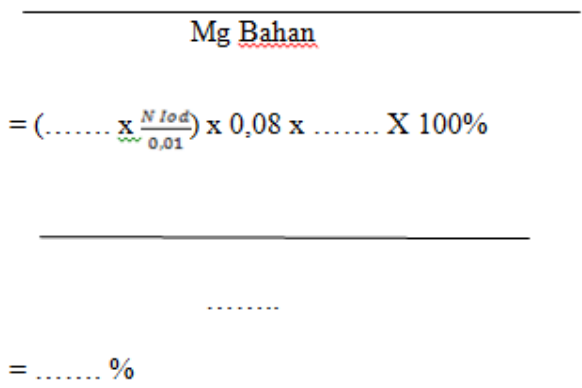

Sumber (Modul kimia amani, 2013).

\section{SAMPEL PENELITIAN}

Sampel penelitian adalah minyak jelantah yang diambil secara acak dari pedagang gorengan di daerah Mulyosari Kota Surabaya sejumlah 5 sampel dari 6 pedagang gorengan di Mulyosari dengan perlakuan sebanyak 5 
kali dan tiap kelompok perlakuan terdiri dari 5 replikasi.

\section{TEKNIK SAMPLING}

Pengambilan sampel dilakukan di pedagang gorengan di Daerah Mulyosari,Surabaya secara acak dengan cara memberikan kode pada setiap lokasi pedagang gorengan kemudian dilakukan pengambilan kertas kode secara acak sebanyak 5 kertas kode.

\section{DEFINISI OPERASIONAL}

Pembuatan serbuk daun kelor, daun kelor dikeringkan pada suhu $50^{\circ} \mathrm{C}$ - $80^{\circ} \mathrm{C}$ selama 90 menit sampai benarbenar kering dan dihaluskan.

Pemberian serbuk daun kelor sebanyak masing-masing 5 gram pada tiap perlakuan kecuali pada kontrol yang kemudian dimasukkan dalam $100 \mathrm{ml}$ sampel minyak jelantah.

Lama perendaman serbuk daun kelor pada tiap perlakuan didiamkan selama satu hari, dua hari, tiga hari, empat hari.

Bilangan peroksida adalah indeks jumlah lemak atau minyak yang telah mengalami oksidasi dan di ukur dengan cara titrasi iodometri dan dinyatakan dalam miliequivalen.

\section{TEKNIK ANALISA DATA}

Untuk mengetahui efektivitas vitamin C pada daun kelor terhadap bilangan peroksida dari minyak jelantah,maka digunakan uji statistik dengan uji ANOVA dengan tingkat kesalahan $0,05 \%$.

\section{HASIL PENELITIAN}

Setelah dilakukan uji efektivitas vitamin C pada daun kelor terhadap bilangan peroksida dari minyak jelantah secara kuantitatif dengan menggunakan metode titrasi iodometri di Laboratorium Kimia Prodi D3 Analis Kesehatan Fakultas Ilmu Kesehatan Universitas Muhammadiyah Surabaya, maka diperoleh rata-rata hasil penelitian sebagai berikut :

Tabel Kadar Vitamin C pada teh daun kelor dalam 10 gram

\begin{tabular}{|c|c|c|c|c|c|}
\hline NO & $\begin{array}{l}\text { Kode } \\
\text { Sampel }\end{array}$ & $\begin{array}{l}\text { Kadar Vita C } \\
\text { teh daun } \\
\text { kelor(mg) }\end{array}$ & NO & Kode Sampel & $\begin{array}{l}\text { Kadar VitC } \\
\text { teh daun } \\
\text { kelor(mg) }\end{array}$ \\
\hline 1 & A1 & $0,0203 \mathrm{mg}$ & 16 & A16 & $0,0193 \mathrm{mg}$ \\
\hline 2 & A2 & $0,0203 \mathrm{mg}$ & 17 & A17 & $0,0204 \mathrm{mg}$ \\
\hline 3 & A3 & $0,0203 \mathrm{mg}$ & 18 & A18 & $0,0203 \mathrm{mg}$ \\
\hline 4 & A4 & $0,0203 \mathrm{mg}$ & 19 & A19 & $0,0203 \mathrm{mg}$ \\
\hline 5 & A5 & $0,0203 \mathrm{mg}$ & 20 & A20 & $0,0203 \mathrm{mg}$ \\
\hline 6 & A6 & $0,0212 \mathrm{mg}$ & 21 & A21 & $0,0202 \mathrm{mg}$ \\
\hline 7 & A7 & $0,0204 \mathrm{mg}$ & 22 & A22 & $0,0203 \mathrm{mg}$ \\
\hline 8 & A8 & $0,0202 \mathrm{mg}$ & 23 & A23 & $0,0203 \mathrm{mg}$ \\
\hline 9 & A9 & $0,0203 \mathrm{mg}$ & 24 & A24 & $0,0203 \mathrm{mg}$ \\
\hline 10 & A10 & $0,0209 \mathrm{mg}$ & 25 & A25 & $0.0212 \mathrm{mg}$ \\
\hline 11 & A11 & $0,0205 \mathrm{mg}$ & 26 & A26 & $0,0202 \mathrm{mg}$ \\
\hline 12 & A12 & $0.2169 \mathrm{mg}$ & 27 & A27 & $0,0203 \mathrm{mg}$ \\
\hline 13 & A13 & $0,0203 \mathrm{mg}$ & 28 & A28 & $0,0203 \mathrm{mg}$ \\
\hline 14 & A14 & $0,0202 \mathrm{mg}$ & 29 & A29 & $0,0224 \mathrm{mg}$ \\
\hline 15 & A15 & $0,0203 \mathrm{mg}$ & 30 & $\mathrm{~A} 30$ & $0,0201 \mathrm{mg}$ \\
\hline \multicolumn{2}{|c|}{ Jumlah } & \multicolumn{4}{|c|}{$0,5920 \mathrm{mg}$} \\
\hline \multicolumn{2}{|c|}{ Rata-rata } & \multicolumn{4}{|c|}{$0,0204 \mathrm{mg}$} \\
\hline
\end{tabular}

\section{PEMBAHASAN}

Hasil penelitian menunjukkan penurunan terhadap kadar vitamin $\mathrm{C}$ pada teh daun kelor yang dikeringkan. Dilihat dari penelitian kadar vitamin $\mathrm{C}$ 
pada teh daun kelor dapat diketahui bahwa ada penurunan kadar vitamin $\mathrm{C}$ dibanding daun kelor segar. Hal ini kemungkinan disebabkan oleh pengeringan dan lama waktu penyimpanan.

Penurunan kadar vitamin $\mathrm{C}$ seiring dengan semakin lamanya waktu penyimpanan, dan pengeringan ini terjadi karena vitamin $\mathrm{C}$ pada teh daun kelor umumnya berupa askorbat, sangat mudah teroksidasi secara reversibel menjadi asam askorbat. Asam askorbat secara kimia sangat labil dan dapat mengalami perubahan lebih lanjut menjadi asam askorbat yang tidak memiliki keaktifan vitamin $\mathrm{C}$ lagi, di peroleh hasil $100 \%$ teh pada daun kelor memenuhi syarat.

Saat penelitian dilaksanakan, proses pengeringan daun kelor dilakukan pada suhu terbuka. Metode ini dilakukan dengan mengambil metode pengeringan yang biasa dipakai oleh para pedagang. Dalam kondisi tersebut, daun kelor mengalami paparan langsung terhadap oksigen dan cahaya matahari sehingga menyebabkan kadar vitamin $\mathrm{C}$ berkurang karena oksidasi (Atmatsier, 2009).

Menurut Sedioetama (2004), kadar vitamin $\mathrm{C}$ juga dapat berkurang karena proses oksidasi oleh oksigen dari udara. Krisdayanto (2004), juga menyebutkan bahwa vitamin $\mathrm{C}$ mudah rusak oleh oksidasi dan dapat dipercepat oleh adanya ion logam seperti tembaga dan besi.

Vitamin C mudah di oksidasi selama pengolahan dan penyimpanan yang dapat mempengaruhi kwalitas bahan pangan. Cahaya merupakan salah satu faktor lingkungan yang mempengaruhi penurunan kadar vitamin C pada daun kelor (Kurniasih, 2013).

Kelor sangat penting untuk penyembuhan berbagai penyakit. Berbagai bagian dari tanaman seperti daun, akar, biji, kulit kayu, buah, bunga dan polong matang, bertindak sebagai stimulan jantung dan peredaran darah, memiliki antitumor, antipiretik, antiepilepsi, antiinflamasi, antiulcer, antispasmodic, diuretik, antihipertensi, penurun kolesterol, antioksidan, antidiabetik, aktivitas hepatoprotektif, antibakteri dan antijamur, dan saat ini sedang digunakan untuk pengobatan penyakit yang berbeda dalam sistem dunia kedokteran, khususnya di Asia Selatan (Dudi,2015).

Pengaruh penambahan antioksida daun kelor terhadap bilangan peroksida

Kadar bilangan peroksida dapat turun disebabkan oleh kandungan antioksidan yang terdapat pada daun kelor. Antioksidan yang terdapat pada daun kelor yaitu komponen 
The Joumal Of Muhammadiyah Medical Laboratory

Vol.2No.2, Mei2019

p-ISSN: 2597-3681 e-ISSN:26142805

fenolik.Komponen fenolik dapat

menghambat radikal bebas dan

menghambat bilangan peroksida

menjadi turun. Daun kelor memiliki

komponen fenolik yang tinggi, menurut

Larson (1998) komponen fenolik yang

dikenal sebagai antioksidan primer dari

tanaman bersifat polar. Menurut chen

and yen (1995) senyawa fenolik dapat

menghentikan reaksi berantai radikal

bebas yang dapat menurukan bilangan

peroksida . (Yuliarti, 2011)

\section{Mengapa harus Daun Kelor ?}

Kelor merupakan tanaman lahan marjinal dan tumbuh terbaik di tempat yang panas, tropis semi kering dan sub tropis. Tanaman Kelor dikenal sebagai tanaman yang ramah bagi para petani dan berguna dari pucuk sampai keakarnya. Kelor cocok untuk daerahdaerah di mana angin kencang dan panjang, kekeringan terjadi secara bersamaan, dan menyebabkan erosi tanah yang serius. Kandungan nutrisi dalam daunnya yang gugur, dapat menyuburkan dan memperbaiki kualitas tanah yang marjinal (Dudi,2015). Oleh karena itu daun kelor selain memiliki antioksidan yang tinggi juga mudah didapatkan di wilayah Surabaya.

\begin{tabular}{|c|c|c|c|c|c|}
\hline \multirow{2}{*}{ Replikasi } & \multicolumn{5}{|c|}{ Kadar Bilangan Peroksida } \\
\cline { 2 - 6 } & P0 & Pl & P2 & P3 & P4 \\
\hline 1 & 23,1921 & 13,9977 & 11,1981 & 7,5988 & 3,1997 \\
\hline 2 & 24,7936 & 15,5991 & 11,5992 & 6,3995 & 4,7998 \\
\hline 3 & 23,5970 & 11,9982 & 9,9983 & 5,1992 & 2,3997 \\
\hline 4 & 23,9973 & 14,7974 & 10,3989 & 5,5995 & 2,7998 \\
\hline 5 & 24,3986 & 15,1997 & 10,7992 & 5,9996 & 1,9998 \\
\hline Jumlah & 119,9786 & 71,5914 & 53,9937 & 30,7966 & 15,1988 \\
\hline Rata-rata & 23,9957 & 14,3182 & 10,7987 & 6,1593 & 3,0397 \\
\hline Std.Deviasi & 0,6331 & 1,4257 & 0,6326 & 0,9206 & 1,0807 \\
\hline
\end{tabular}

Sumber (Lab. Kimia, 2017)

Keterangan :

P0 : Tanpa perendaman serbuk daun kelor

P1 : Dengan perendaman serbuk daun kelor selama 1 hari

P2 : Dengan perendaman serbuk daun kelor selama 2 hari

P3 : Dengan perendaman serbuk daun kelor selama 3 hari

P4 : Dengan perendaman serbuk daun kelor selama 4 hari

Dari tabel di atas dapat dilihat bahwa pada minyak jelantah sebelum perendaman serbuk daun kelor memiliki rata-rata bilangan peroksida sebesar 23,9957 mEq. Setelah direndam serbuk daun kelor selama 1 hari,rata-rata bilangan peroksida minyak jelantah sebesar 14,3182,sedangkan minyak jelantah yang direndam dengan serbuk daun kelor selama 2 hari memiliki ratarata kadar bilangan peroksida sebesar 10,7987. Rata-rata kadar bilangan peroksida pada perendaman serbuk daun kelor selama 3 hari pada minyak jelantah sebesar 6,1593 dan rata-rata kadar bilangan peroksida pada perendaman serbuk daun kelor selama 4 
hari pada minyak jelantah sebesar 3,0397

\section{SIMPULAN DAN SARAN}

\section{Simpulan}

Dari hasil penelitian kadar vitamin $\mathrm{C}$ pada teh daun kelor yang dikeringkan diperoleh kesimpulan bahwa kadar vitamin $\mathrm{C}$ pada teh daun kelor yang dikeringkan rata-rata adalah $0,0204 \mathrm{mg}$ dalam $10 \mathrm{gr}$ atau $0,204 \mathrm{mg}$ dalam 100 gr teh daun kelor.

Dari hasil penelitian uji daya hambat perendaman serbuk daun kelor (Moringa oleifera) terhadap kadar bilangan peroksida pada minyak goreng jelantah dapat diambil kesimpulan bahwa :

1. Diperoleh ada efektivitas vitamin $\mathrm{C}$ pada daun kelor terhadap (Moringa oleifera) terhadap kadar bilangan peroksida pada minyak goreng jelantah

2. Angka rata-rata Bilangan Peroksida sebelum perendaman serbuk daun kelor yaitu 23,9957

Angka rata-rata Bilangan Peroksida sesudah perendaman serbuk daun kelor hari $1(14,3182)$, hari $2(10,7987)$, hari 3 $(6,1593)$, hari $4(3,0397)$

\section{DAFTAR PUSTAKA}

Adina, Manfaat Vitamin, Komunitas Bloger Universitas Sriwijaya. http:

//ww.femina.co.id/isu.wanita/ke sehatan/mengenal.manfaat.vitam in.c.dan.imunitas.tubuh /005/005/205

Ahmad jauhari, M.Sc (2013), Dasardasar ilmu gizi Karbohidrat, Protein, Vitamin, Yogyakarta.

Ana Tri Setyowati, 2011, Pengaruh suhu, dan lama pengeringan terhadap vitanin $A$, dan vitamin $C$, serta aktivitas antioksida daun kelor (Moringa olifera Lam), UPN "Veteran" Jawa Timur.

Aulia Rani Annisava, 2013, Optimalisasi pertumbuhan dan kandungsn vitamin $C$ kailan (Brassica alblograba L)Menggunakan bokashi serta ekstrak tanaman terfermentasi Fakultas Pertanian dan Peternakan Universitas Islam Negri Sultan Sayarif Kasim Riau.

Dede Aditiya Rachman, 2011, Efek Serbuk Daun Kelor, Fakultas Kedokteran Unifersitas Brawijaya.

Fatchurrozak, Santoso, dan sugiyanto, (2013), Pengaruh ketinggian dan tempat terhadap kandungan vitanin $C$, Mahasiswa Prodi Biosain UNS.

Fifi Lutifiah, (2012), potensi gizi daun kelor, mtaram. 
Guntur Argana, Kusharusupeni, Dian M Utari, (2004), Vitamin sebagai faktor domonan kadar hemoglobin pada wanita usia 20 - 35 tahun, Pusat Kesehatan kerja, Dapertemen kesehatan RI, Dapertemen Gizi kesehatan masyarakat, FKM-UI

Idmbang Dwi Rahayu.M.Kes, 2009,Klasifikasi fungsi dan Metabolisme vitamin, Fakultas Pertanian - Peternakan, Universitas muhammadiyah Malang.

Jomla, (2003), Manfaat vitamin C dari masa kemasa, http://agro.agroprima.com.

Kmelia, (2006), pola komsumsi teh di indonesia, Kota baru Jambi.

Kurniasih, 2013, kasist manfaat Daun kelor untuk penyembuhan berbagai penyakit, penerbit. Jogjakarta.
Laras Andrian Wardani, (2012), Validasi metode analisis dan penetuan kadar vitamin $C$ pada minuman kemasan, Universitas Indonesia.

Rika Yulianti, 2008, Pembuat minumam daun kelor (Moringa Oleifera lemak) Sebagai sumber vitanin $C$, Program studi gizi masyarakat dan sumber daya keluarga fakultas pertanian Institut pertanian Bogor.

Sandara Kartika, (2011), 10 alasan untuk minum teh setiap hari, http://www.teen.co.id/teenmagazine/teenklopedia/170-10alasan-untuk-minum-teh-setiaphari.html.

Sri Wulandari, (2010), Uji protein,vitamin $C$, dan air, Yogyakarta.

Titin Andrian Wihastuti, 2007. Efek ekstak daun kelor, Jurnal Kardiologi indonesia. Vol 28, No 3 Mei 2007 
